\section{BA Institute of \\ YK Business Administration \\ 六下 \\ Karachi \\ Leadership and Ideas for Tomorrow}

Business Review

Volume 15 Issue 1

January-June 2020

$1-1-2020$

\title{
Deciphering brand loyalty through brand association and emotional confidence
}

\author{
Amber Gul Rashid \\ Institute of Business Administration, Karachi, Pakistan \\ Wajid Hussain Rizvi \\ Institute of Business Administration, Karachi, Pakistan \\ Huma Amir \\ Institute of Business Administration, Karachi, Pakistan
}

Follow this and additional works at: https://ir.iba.edu.pk/businessreview

Part of the Finance Commons, Management Sciences and Quantitative Methods Commons, and the Marketing Commons

\section{(c) (1)}

This work is licensed under a Creative Commons Attribution 4.0 International License.

\section{Recommended Citation}

Rashid, A. G., Rizvi, W. H., \& Amir, H. (2020). Deciphering brand loyalty through brand association and emotional confidence. Business Review, 15(1), 97-107. Retrieved from https://doi.org/10.54784/ 1990-6587.1012

This article is brought to you by iRepository for open access under the Creative Commons Attribution 4.0 License and is available at https://ir.iba.edu.pk/businessreview/vol15/iss1/13. For more information, please contact irepository@iba.edu.pk. 


\title{
Deciphering brand loyalty through brand association and emotional confidence
}

\author{
Amber Gul Rashid . \\ Wajid Hussain Rizvi · Huma Amir
}

\begin{abstract}
This paper investigates the influence of emotional confidence and brand association on brand loyalty and whether there is a statistically significant difference in the brand loyalty of consumers having low or high emotional confidence. Data was collected outside fast food restaurants across Karachi using systematic sampling. Every fourth person exiting the restaurant was approached to fill a questionnaire. The data was analyzed using structural equation modelling. The results suggest that both brand association and emotional confidence have a statistically significant influence on brand loyalty. The variance explained in brand loyalty was higher when emotional confidence was included in the model. The result of the independent sample t-test suggests that there is a statistically significant difference between consumers having low and high emotional confidence in terms of their brand loyalty. Consumers with higher emotional confidence showed higher brand loyalty ${ }^{1}$.
\end{abstract}

Keywords Brand loyalty · Brand association · Emotional confidence ·

Emotional attachment

\section{Introduction}

Brand association and brand loyalty have been at the center of academic investigation and are strategically important to practitioners. The topic of brand

Amber Gul Rashid

Institute of Business Administration, University Road, Karachi-Pakistan

E-mail: arashid@iba.edu.pk

Wajid Hussain Rizvi

Institute of Business Administration, University Road, Karachi-Pakistan

Huma Amir

Institute of Business Administration, University Road, Karachi-Pakistan

(C)Rashid, G. A., Rizvi. H. W. and Amir, H. 2020

1 An adapted version of this abstract was published in the Academy of Marketing Science Conference, 2018; available at https : //link.springer.com/content/pdf/10.1007\%2F978-3$319-99181-86 . p d f ;$ last accessed on 30th January 2019 
A. Rashid et al.

loyalty and its linkages with different aspects of consumer behavior have been discussed (Gounaris and Stathakopoulos 2004). The importance of loyalty is well-recognized in marketing literature (Griffin and Herres 2002). Gounaris and Stathakopoulos (2004) emphasize the link between premium loyalty, customer retention, and emotional attachment.

Associations are essential to decipher consumer brand relationships (Krishnan 1996). Londoño et al (2016) recently conducted a seminal study on the topic and proposed a model where association is one of the antecedents of consumer based brand-retailer-channel equity, the other antecedents being loyalty and perceived quality. Self-confidence (Bearden et al 2001) and emotional calibration (Kidwell et al 2008) have also been studied in the context of consumer behavior. Rizvi and Oney (2018) have discussed emotional confidence and its implications for purchase behavior.

Until now, no study has demonstrated the influence of emotional confidence on brand loyalty. This study investigates the influence of brand association and emotional confidence on brand loyalty in the context of a leading fast food brand. The following research questions have been studied:

1. Does brand association influence brand loyalty?

2. Does emotional confidence influence brand loyalty?

3. Does inclusion of emotional confidence in the model increase the variance explained in brand loyalty?

4. Are consumers with lower emotional confidence significantly different from consumers with higher emotional confidence in terms of brand loyalty?

\section{Background and hypotheses development}

Aaker (1991) defines brand loyalty as a relationship between the customers and a brand where customers become attached to the brand and continue to prefer and buy it over a period of time and in the face of competition. Chaudhuri and Holbrook (2001) mention behavior and attitudinal loyalty as two aspects of brand loyalty (Chi et al 2009) while Wilson and Persson (2017) state that brand loyalty has mental and behavioral dimensions. In his study, Vinh (2017) employed the attitudinal aspect of brand loyalty and confirmed that it is positively related to brand equity. Brand loyalty and its attributes are also related to word of mouth (Gounaris and Stathakopoulos 2004), share of the market, (Chaudhuri and Holbrook 2001), financial performance of the firm (Kim et al 2003), and increased possibility of offering premium prices (Chaudhuri and Holbrook 2001). Further, Veloutsou (2015) found that good consumer brand relationship plays an important role in establishing brand loyalty.

Loyal customers are less price sensitive which means brand loyalty can help the brand deal with threats from its competitors (Ahmad and Sherwani 2015). Kumar et al (2016) confirmed that price increase by a preferred apparel brand will not change the brand preference of the customer. Sallam and Wahid (2015) emphasize the advantages a business can gain by fostering brand loyalty. The role of brand association in fostering brand loyalty has also been studied (Chow et al 2017). Customer satisfaction has a strong link with brand loyalty (Susanty 
and Kenny 2015). Increasingly, marketers are turning to social media to assess how it can be used to enhance brand loyalty (Ismail 2017). Loyalty can exist as covetous, premium, inertia, or no loyalty depending on the combination of social influences, emotional attachment, and purchase behavior (Gounaris and Stathakopoulos 2004). It is argued in this paper that emotional confidence is a consequence of consumers' emotional responses, bonding, and attachment towards a brand and, along with brand association, is an important factor that needs to be monitored in relation to brand loyalty.

\subsection{Brand Association $\rightarrow$ Brand Loyalty}

One of the ways in which researchers have attempted to explain brand associations is by adopting the associative network memory model from cognitive psychology (Gordon et al 2016; Teichert and Schöntag 2010; Chen 2001; Krishnan 1996; Keller 1993). The model states that memory is stored in a network of informational nodes. When an external stimulus triggers one node, the effect ripples across these multiple memory files (nodes) and elicits associations (Teichert and Schöntag 2010). Thus, brand associations may be thought of as consisting of all the information stored in a consumer's mind that he/she connects with a brand (Korchia 2000).

In his "Brand Equity Ten" model, Aaker (1996) considered both awareness and association as important antecedents of brand equity. Later, Ahmad and Sherwani (2015) postulated that awareness should precede association since information must be present in some form in order to develop any kind of links or associations (Washburn and Plank 2002). Consumers are said to move through various stages of awareness: from being completely unaware of the brand to brand recognition, brand recall, and finally to high brand awareness (Chow et al 2017). Keller (1993) proposed that with increasing familiarity with the brand, consumer brand associations increase along the dimensions of an understanding of brand attributes, perception of benefits derived from the brand, and the formation of attitudes towards the brand (Chow et al 2017; Keller et al 2011; Qu et al 2011; Vinh 2017).

Brand associations have been the topic of seminal research through time. They may relate to a brand's emotional aspects, tangible aspects, or both (AQader et al 2017). Additionally, brand association may be further categorized into product association - where a consumer stores impressions about the product itself - and organizational association (Aaker 1996) which relates to memory about the brand's organization (Atilgan et al 2005; Chen 2001). While Del Río et al (2001) focused on the importance of brand names, Low and Lamb (2000) established that brand image, brand attitude, and perceived quality are three separate and distinct dimensions of brand associations.

Gordon et al (2016) have separated the dimensions that measure associations of goods versus services brands by putting forth the argument that differences exist in their nature, hence calling for separate treatment. James (2005) highlighted the link between brand associations and attitudes towards new alliances. According to Parker (2015), brand associations can be negative as well as pos-

Business Review: (2020) 15(1):97-107 
A. Rashid et al.

itive (Keller 2003), depending on the information a person has related to the brand in his/her mind.

Contact between consumers and brands helps trigger and shape brand associations (Buil et al 2013). Low and Lamb (2000) proved that for familiar brands the brand association measures are multidimensional but may be unidimensional for lesser known brands. In other words, the more associative linkages of a brand the consumer has in his/her memory bank, the better he/she will be able to remember it and the higher would be the probability of loyalty towards the brand (Sasmita and Suki 2015) when the associations are positive. Atilgan et al (2005) confirmed correlation between brand awareness and brand associations while Yoo et al (2000) cautioned against excessive use of price promotion as it triggers association with price deals rather than with the brand attributes and, as a consequence, does not help to foster positive brand associations. They posit that in fact, excessive promotions may trigger negative associations. Additionally, the authors did not find any relationship between either price and brand loyalty or price and brand associations.

Alexandris et al (2008) proved that brand associations significantly predicted brand loyalty. Similarly, Yoo et al (2000) showed that there is significant positive correlation between brand associations and brand loyalty, which further impacts brand equity. Various other studies have suggested the relationship between brand associations and brand loyalty, such as Ross et al (2006) and Keller (2003). Thus, the following hypothesis is developed:

H1: Brand Association has positive influence on Brand Loyalty

\subsection{Emotional Confidence $\rightarrow$ Brand Loyalty}

Traditionally, researchers pointed out that rational decision making had long been the topic of many studies (Ajzen and Fishbein 1980; Ajzen 1985) but irrational decision making, which has historically been considered the outcome of feelings and emotions, has not received due attention (Pham et al 2001). Human behavior is unpredictable at best and Pham (2007) cautions against generalization of behaviour elicited by rational or irrational state of emotions, putting forward the theory that while the physiological driving forces caused by physical feelings tend to be self-serving, the affective evaluative system of emotions takes into consideration the social and moral aspects of actions. Bechara and Damasio (2005) also suggest rational decision making depends on prior emotional processing, the suggestion was based on neuroscience evidence.

Zajonc (1980) points out that even though people may think that they are basing their decision on rational thought, their likes and dislikes may come into play without their being aware of it. In an interesting study, Moorman et al (2004) looked at the interplay between self-consistency and subjective knowledge and the role of the latter in influencing consumer choices. Emotions can and often do influence decision making (Damasio 1994; Reid and González-Vallejo 2009).

Emotional calibration can also play a part in consumer decision making (Kidwell et al 2008). In academic literature confidence as a construct is defined 
as a feeling of certainty and absurdness (Compte and Postlewaite 2004; Stajkovic 2006). It is postulated that the feeling of certainty propels confidence as a consequence a person would engage in behavioural response. It thereby follows that this feeling of certainty is potentially a triggering factor that enables us to act. Hence, there seems to be a connection between confidence and emotions whereby confidence is strengthened, or at least partially triggered, by emotional feelings.

Consumers can become attached to brands and this emotional attachment may result in repurchases (Grisaffe and Nguyen 2011). When consumers become emotionally attached/bonded to a brand, this leads to increased commitment and willingness to spend more (Thomson et al 2005). Carroll and Ahuvia (2006) test the concept of "brand love" - very strong positive emotional attachment towards a brand - and conclude that brand love has a positive impact on brand loyalty and favourable word-of-mouth.

Both emotional bonds and confidence, among other factors, have an impact on customer loyalty (Lima and Fernandes 2015), and emotional bonds between customers and organizations act as barriers for competitors (Berry et al 2002). By designing and executing great customer experiences (Schmitt 2010) which also appeal to the customers emotions, loyalty can be enhanced (Deming 2007; Haeckel et al 2003). When customers are constantly satisfied by the supplier, they have confidence that their expectation will be met in the future as well. Consequently, they are willing to continue the satisfying relationship.

While acknowledging the influence satisfaction has on loyalty, Stauss and Neuhaus (1997) point out that many satisfied customers could potentially leave a supplier for another competitor unless the supplier continuously improves its offering to match increasing customer expectations. Iglesias et al (2011) demonstrate that brand experience developed through affective commitment influences brand loyalty. In view of the preceding discussion, the following hypothesis is developed:

H2: Emotional Confidence has an influence on Brand Loyalty

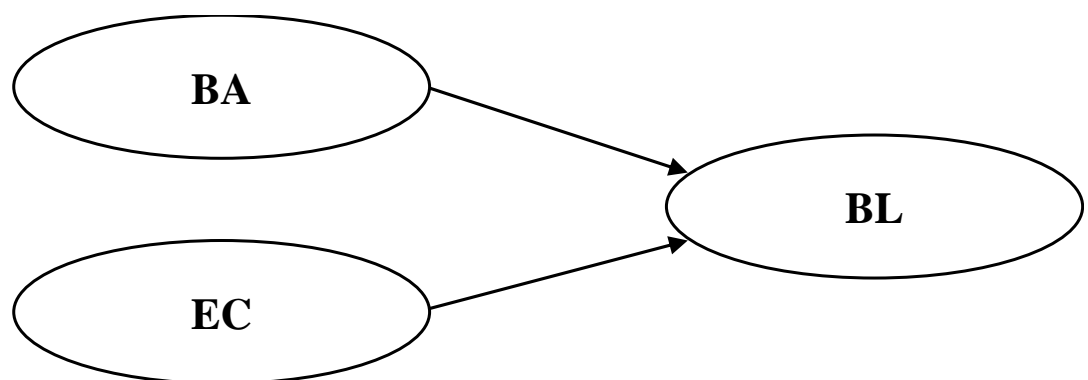

Fig. 1: Conceptual Framework BA (Brand Association); EC (Emotional Confidence); BL (Brand Loyalty) 
A. Rashid et al.

\section{Methodology}

This study was conducted in the context of a leading fast food brand (restaurant chain). Data was collected from respondents outside fast food restaurants across Karachi by using systematic sampling. Prior to that the restaurants were randomly selected and were approached for data collection consent. Every fourth person exiting the restaurant was approached to fill out the questionnaire. 532 respondents were approached; 266 respondents agreed to fill the questionnaire. After scrutiny, 14 responses were discarded as they were partially complete. Hence response rate was $47.3 \%$ and $n=252$.

It is argued that convenience or student sampling technique limits generalizability of a study (Sears 1986). In order to enhance generalizability, probability sampling is advised such as simple random sampling (Hair et al 2007). However, to collect data using simple random sampling of all users was not feasible because of budget and time limitations; viewing the limitations, use of systematic sample was a better option. To address the issue of generalizability use of the systematic sampling is preffered compared to convenience non probability sampling (Hair et al 2007).

For all constructs, (brand association, emotional confidence, and brand loyalty), validated scales were used (Rizvi and Oney 2018; Yoo et al 2000). After assessment of construct dimensionality as per authors' scale guidelines, it was concluded that all constructs involved had one dimension. All constructs were reliable based on Cronbach Alpha (> .7). After preliminary analysis, the hypothesized model was analyzed using structural equation modeling (AMOS 21). Independent t-test was used to assess if there was statistically significant difference between respondents having higher and lower emotional confidence in terms of their brand loyalty towards the brand.

\section{Results}

Before analyzing the structural model, preliminary analysis was conducted which included dimensionality, reliability and average variance extracted (AVE). Table 1 shows observed scores. The observed AVE of all constructs was higher than the recommended threshold $(>0.50)$; the observed Cronbach alpha of all scores was higher than the recommended threshold $(>0.70)$ and all constructs were unidimensional with eigenvalues greater than one $(>1)$.

The hypothesized model was tested through structural equation model for

Table 1: Observed values

\begin{tabular}{lccc}
\hline Construct & Observed AVE & Cronbach Alpha & Dimension \& Eigenvalue \\
\hline Brand Association & 0.59 & 0.84 & One $2.74(68.5 \%)$ \\
Emotional Confidence & 0.69 & 0.85 & One 2.32 (77.5\%) \\
Brand Loyalty & 0.81 & 0.89 & One $1.81(90 \%)$ \\
\hline
\end{tabular}

the influence of brand association and emotional confidence on brand loyalty

Business Review: (2020) 15(1):97-107 
and the overall model fit was analyzed. Table 2 shows regression coefficient, statistical significance and model fit indices.

It is important to note that when emotional confidence was removed from

Table 2: Regression coefficient, statistical significance and model fit indices

\begin{tabular}{ll}
\hline \multicolumn{3}{l}{ Both emotional confidence and brand association as exogenous variables } \\
\hline $\mathrm{BAs} \rightarrow \mathrm{BL}$ & $\beta=0.72(\mathrm{P}<0.001)$ \\
$\mathrm{EC} \rightarrow \mathrm{BL}$ & $\beta=0.19(\mathrm{P}<0.001)$ \\
Variance Explained: $\mathrm{BL}$ & 0.71 \\
Absolute fit indices & $\chi^{2}=51.94 ; \chi^{2} / \mathrm{df}=2.25 ;(\mathrm{P}<0.001)$ \\
Comparative fit indices & $\mathrm{CFI}=0.979 ; \mathrm{TLI}=0.96 ; \mathrm{RMESA}=0.07 ; \mathrm{IFI}=0.97 ; \mathrm{NFI}=0.96$ \\
Predictive fit indices & $\mathrm{SRMR}=0.03 ; \mathrm{GFI}=0.955 ; \mathrm{AGFI}=0.911 ; \mathrm{PGFI}=0.48$ \\
\hline Only brand association as exogenous variable \\
$\begin{array}{ll}\text { BAs } \rightarrow \mathrm{BL} & =.79(\mathrm{P}<0.001) \\
\text { Variance Explained: } \mathrm{BL} & 0.62\end{array}$ \\
\hline
\end{tabular}

the model, overall variance explained in brand loyalty reduced from $71 \%$ to $62 \%$. This shows that the inclusion of emotional confidence in the model increases the explanation of brand loyalty and all model fit indices showed that the model was fit.

Furthermore, it was investigated whether there is a statistically significant difference between respondents having high and low emotional confidence in terms of brand loyalty. Table 3 shows the result of independent sample t-test suggesting that there is a statistically significant difference between the two groups. Respondents having higher emotional confidence had higher brand loyalty than respondents having lower emotional confidence. Table 4 shows hypotheses affir-

Table 3: Result of independent sample t-test

\begin{tabular}{lcccc}
\hline \multicolumn{1}{l}{ Independent Sample Test } & & & \\
\hline Brand Loyalty & Mean & t value $(\mathrm{df})$ & Mean diff & Significance \\
\hline Low Emotional Confidence & 7.23 & $-6.99(250)$ & -2.68 & $000(\mathrm{p}<0.001)$ \\
High Emotional Confidence & 9.91 & & & \\
\hline
\end{tabular}

mation: results based on structural equation modeling and independent sample test suggest that all three hypotheses were affirmed.

Table 4: Hypotheses affirmation

\begin{tabular}{ll}
\hline Hypothesis & Hypotheses affirmation \\
\hline $\mathrm{H} 1-\mathrm{BAs} \rightarrow \mathrm{BL}$ & Affirmed $(\mathrm{p}<0.001)$ \\
$\mathrm{H} 2-\mathrm{EC} \rightarrow$ BL & Affirmed $(\mathrm{p}<0.001)$ \\
$\mathrm{H} 3-$ High Low & Affirmed $(\mathrm{p}<0.001)$ \\
Emotional confidence $\rightarrow$ BL & \\
\hline
\end{tabular}

Business Review: (2020) 15(1):97-107 
A. Rashid et al.

\section{Conclusion and managerial implications}

Brands surround us in our everyday life and our relationship with them influences our purchase behavior. Emotional attachment is considered one of the major factors in determining premium loyalty as opposed to habitual buying. This study further demonstrates that the consumers' affective certainty (in other words emotional confidence) towards a brand can be helpful in assessing brand loyalty. The empirical result affirms that there is a statistically significant impact of brand association as well as emotional confidence on brand loyalty.

The relationship between brand association and brand loyalty has been widely reported in academic literature but this study provides a new perspective of how affective certainty (i.e. emotional confidence) also influences brand loyalty. Our results show that inclusion of emotional confidence in the model increased variance explained in brand loyalty suggesting that it can be an essential determinant of brand loyalty. Consumers' group comparison (low confidence and high confidence) in terms of their brand loyalty suggested that consumers having higher emotional confidence were statistically higher on brand loyalty than consumers having low emotional confidence.

Emotional confidence and brand association as determinants of brand loyalty entail managerial implications. This finding provides emotional confidence as an index, in addition to established indices like brand attachment and brand association, to further understand the nature of brand loyalty. From the practitioners' perspective, two factors are of integral importance: revenue generation and long term sustainability of a brand. Tracking emotional confidence over a period of time would be helpful for practitioners in achieving long term sustainability of a brand and higher returns. It is important to note that this study is a preliminary study using emotional confidence as a determinant of brand loyalty. Future studies will further highlight whether emotional confidence towards a brand can be helpful in specifying whether brand loyalty is sustainable in the long run or whether it is merely habitual.

\section{References}

A-Qader IK, Omar AB, Rubel MRB (2017) The influence of affective brand experience dimension on brand equity of the smartphone millennial users in malaysia. Management $5(1): 25-37$

Aaker DA (1991) Managing brand equity. Macmillan, New York, NY

Aaker DA (1996) Measuring brand equity across products and markets. California Management Review 38(3):102-20

Ahmad F, Sherwani NU (2015) An empirical study on the effect of brand equity of mobile phones on customer satisfaction. International Journal of Marketing Studies 7(2):59

Ajzen H, Fishbein M (1980) Understanding attitudes and predicting social behavior. Prentice Hall Englewood Cliffs, NJ

Ajzen I (1985) From intentions to actions: A theory of planned behavior. In: Action control, Springer, pp 11-39

Alexandris K, Douka S, Papadopoulos P, Kaltsatou A (2008) Testing the role of service quality on the development of brand associations and brand loyalty. Managing Service Quality: An International Journal 18(3):239-254

Atilgan E, Aksoy Ş, Akinci S (2005) Determinants of the brand equity. Marketing intelligence \& planning $23(3): 237-248$ 
Bearden WO, Hardesty DM, Rose RL (2001) Consumer self-confidence: Refinements in conceptualization and measurement. Journal of Consumer Research 28(1):121-134

Bechara A, Damasio AR (2005) The somatic marker hypothesis: A neural theory of economic decision. Games and Economic Behavior 52(2):336-372

Berry LL, Carbone LP, Haeckel SH (2002) Managing the total customer experience. MIT Sloan Management Review 43(3):85-89

Buil I, De Chernatony L, Martínez E (2013) Examining the role of advertising and sales promotions in brand equity creation. Journal of Business Research 66(1):115-122

Carroll BA, Ahuvia AC (2006) Some antecedents and outcomes of brand love. Marketing letters 17(2):79-89

Chaudhuri A, Holbrook MB (2001) The chain of effects from brand trust and brand affect to brand performance: the role of brand loyalty. Journal of Marketing 65(2):81-93

Chen ACH (2001) Using free association to examine the relationship between the characteristics of brand associations and brand equity. Journal of Product \& Brand Management 10(7):439-451

Chi H, Yeh H, Yang Y (2009) The impact of brand awareness on consumer purchase intention: The mediating effect of perceived quality and brand loyalty. Journal of International Management Studies 4(1):135-144

Chow Hw, Ling GJ, Yen Iy, Hwang KP (2017) Building brand equity through industrial tourism. Asia Pacific Management Review 22(2):70-79

Compte O, Postlewaite A (2004) Confidence-enhanced performance. American Economic Review 94(5):1536-1557

Damasio AR (1994) Descartes' error. emotion, reason and the human brain. G P Putnam's Sons, a divison of the Putnam Berkely Group, Inc New York 10016

Del Río AB, Vazquez R, Iglesias V (2001) The role of the brand name in obtaining differential advantages. Journal of Product \& Brand Management 10(7):452-465

Deming S (2007) The Brand Who Cried Wolf: Deliver on Your Company's Promise and Create Customers for Life. John Wiley \& Sons, Inc., Hoboken, New Jersey

Gordon BS, James JD, Yoshida M (2016) The development of brand association measures in multiple product categories: New findings and implications for goods and service brands

Gounaris S, Stathakopoulos V (2004) Antecedents and consequences of brand loyalty: An empirical study. Journal of Brand Management 11(4):283-306

Griffin J, Herres RT (2002) Customer loyalty: How to earn it, how to keep it. Jossey-Bass San Francisco, CA

Grisaffe DB, Nguyen HP (2011) Antecedents of emotional attachment to brands. Journal of Business Research 64(10):1052-1059

Haeckel SH, Carbone LP, Berry LL (2003) How to lead the customer experience. Marketing Management 12(1):18-18

Hair JF, Money AH, Samouel P, Page M (2007) Research methods for business. John Wiley $\&$ Sons, West Sussex, England

Iglesias O, Singh JJ, Batista-Foguet JM (2011) The role of brand experience and affective commitment in determining brand loyalty. Journal of Brand Management 18(8):570-582

Ismail AR (2017) The influence of perceived social media marketing activities on brand loyalty. Asia Pacific Journal of Marketing and Logistics 29(1):129-144

James D (2005) Guilty through association: brand association transfer to brand alliances. Journal of Consumer Marketing 22(1):14-24

Keller KL (1993) Conceptualizing, measuring, and managing customer-based brand equity. Journal of Marketing 57(1):1-22

Keller KL (2003) Brand synthesis: The multidimensionality of brand knowledge. Journal of Consumer Research 29(4):595-600

Keller KL, Parameswaran M, Jacob I (2011) Strategic brand management: Building, measuring, and managing brand equity. Pearson Education India

Kidwell B, Hardesty DM, Childers TL (2008) Emotional calibration effects on consumer choice. Journal of Consumer Research 35(4):611-621

Kim Hb, Kim WG, An JA (2003) The effect of consumer-based brand equity on firms financial performance. Journal of Consumer Marketing 20(4):335-351

Korchia M (2000) Brand image and brand associations. ESSEC

Krishnan HS (1996) Characteristics of memory associations: A consumer-based brand equity perspective. International Journal of Research in Marketing 13(4):389-405

Business Review: (2020) 15(1):97-107 
A. Rashid et al.

Kumar MMS, Kumar DP, Narayana MS (2016) Impact of brand equity on customers purchase decision making while choosing branded over unbranded apparel in andhra pradesh. International Journal of Applied Engineering Research 11(7):5202-5209

Lima M, Fernandes T (2015) Relationship bonds and customer loyalty: A study across different service contexts. In: International Conference on Exploring Services Science, Springer, pp 326-339

Londoño JC, Elms J, Davies K (2016) Conceptualising and measuring consumer-based brandretailer-channel equity. Journal of Retailing and Consumer Services 29:70-81

Low GS, Lamb CW (2000) The measurement and dimensionality of brand associations. Journal of Product \& Brand Management 9(6):350-368

Moorman C, Diehl K, Brinberg D, Kidwell B (2004) Subjective knowledge, search locations, and consumer choice. Journal of Consumer Research 31(3):673-680

Parker BT (2015) The influence of brand equity on consumer response toward environmental product advertisements. Studies in Media and Communication 3(1):117-126

Pham MT (2007) Emotion and rationality: A critical review and interpretation of empirical evidence. Review of general psychology 11(2):155-178

Pham MT, Cohen JB, Pracejus JW, Hughes GD (2001) Affect monitoring and the primacy of feelings in judgment. Journal of consumer research 28(2):167-188

$\mathrm{Qu} \mathrm{H}$, Kim LH, Im HH (2011) A model of destination branding: Integrating the concepts of the branding and destination image. Tourism management 32(3):465-476

Reid AA, González-Vallejo C (2009) Emotion as a tradeable quantity. Journal of Behavioral Decision Making 22(1):62-90

Rizvi WH, Oney E (2018) The influence of emotional confidence on brand attitude: using brand belief as mediating variable. Economic research-Ekonomska istraživanja 31(1):158170

Ross SD, James JD, Vargas P (2006) Development of a scale to measure team brand associations in professional sport. Journal of sport management 20(2):260-279

Sallam MA, Wahid NA (2015) The effects of satisfaction and brand identification on brand love and brand equity outcome: the role of brand loyalty. European Journal of Business and Social Sciences 4(9):42-55

Sasmita J, Suki NM (2015) Young consumers' insights on brand equity. International Journal of Retail \& Distribution Management 43(3):276-292

Schmitt BH (2010) Customer experience management: A revolutionary approach to connecting with your customers. John Wiley \& Sons

Sears DO (1986) College sophomores in the laboratory: Influences of a narrow data base on social psychology's view of human nature. Journal of personality and social psychology 51(3):515

Stajkovic AD (2006) Development of a core confidence-higher order construct. Journal of Applied Psychology 91(6):1208-1224

Stauss B, Neuhaus P (1997) The qualitative satisfaction model. International Journal of Service Industry Management 8(3):236-249

Susanty A, Kenny E (2015) The relationship between brand equity, customer satisfaction, and brand loyalty on coffee shop: Study of excelso and starbucks. ASEAN Marketing Journal pp $14-27$

Teichert TA, Schöntag K (2010) Exploring consumer knowledge structures using associative network analysis. Psychology \& Marketing 27(4):369-398

Thomson M, MacInnis DJ, Whan Park C (2005) The ties that bind: Measuring the strength of consumers emotional attachments to brands. Journal of Consumer Psychology 15(1):77-91

Veloutsou C (2015) Brand evaluation, satisfaction and trust as predictors of brand loyalty: the mediator-moderator effect of brand relationships. Journal of Consumer Marketing 32(6):405-421

Vinh TT (2017) Measuring customer based brand equity: a case of heineken from the beer market in vietnam. Asian Social Science 13(3):177-184

Washburn JH, Plank RE (2002) Measuring brand equity: An evaluation of a consumer-based brand equity scale. Journal of Marketing Theory and Practice 10(1):46-62

Wilson A, Persson N (2017) The interplay between brand loyalty and brand satisfaction: A qualitative study of consumers in the clothing industry

Yoo B, Donthu N, Lee S (2000) An examination of selected marketing mix elements and brand equity. Journal of the Academy of Marketing Science 28(2):195-211 
https://ir.iba.edu.pk/businessreview/vol15/iss1/13

DOI: https://doi.org/10.54784/1990-6587.1012

Deciphering brand loyalty...

Zajonc RB (1980) Feeling and thinking: Preferences need no inferences. American Psychologist $35(2): 151$

Business Review: (2020) 15(1):97-107 